dates who are chosen from Swiss academic institutions according to the specific requirements of the foundation. The Basel Institute for Immunology, which houses 50 basic-research scientists, is also financed by Roche.

There are a number of reasons why Swiss drug companies invest internationally. First, expertise cannot always be found nationally, even when a company has vast in-house $R \& D$ operations. Worldwide collaborations also reflect Swiss companies' sales; for example, 96 per cent of Sandoz sales are outside Switzerland. Drug companies are discouraged from new long-term investment in Switzerland because of strict laws on animal experiments. A recent referendum rejected a complete ban, but drug companies remain wary.

France's largest pharmaceutical company, Rhône-Poulenc, sponsors much academic research. But this may be about to change. The government is at present selling 20 per cent of the shares to the public, but the conservative opposition, tipped to take over power after the elections later this year, has pledged to privatize the company completely. This move could ultimately affect non-commercial academic research projects. Rhône-Poulenc's academic research activity is guided by the Directions Scientifiques. The company offers studentships and also, to the country's best young scientists, the chance of doing strategic research for the company instead of military service. Rhône-Poulenc partly sponsors the Bioavinor programme with the Ministries of Research and Industry. The project costs FFr1.6 billion ( $\$ 290$ million) and aims to define the basic research needs of the company. RhônePoulenc also spends FFr0.2 billion on a five-year project with public research institutes. The institutes set the scientific agenda.

Roussel Uclaf has seven research agreements with universities and research institutes in France, including the state-financed CNRS, INSERM and INRA. The company has similar agreements with European universities and also attracts scientists for the Tables Rondes, a forum for scientific debate independent of company business. The biennial Roussel prize is awarded to a scientist researching in chemistry or biology of steroids.

\section{Making partnerships work}

IN the $1980 \mathrm{~s}$, the departments of pharmacology at the Universities of Oxford and Cambridge found themselves in a similar position. Like everyone else, they faced a future of diminishing research funding opportunities. But at the same time they were both desperately in need of new laboratory facilities. They both courted the drug industry for help, successfully in each case but with different styles.

At Oxford, head of department David Smith hosted a workshop in 1986 to demonstrate to industry what his department had to offer in terms of a basic research environment. The idea of major collaborative projects was quite new in Britain at that time and, according to Smith, many companies were unable to accept that research in the department would continue to be fundamental and freely chosen - at all costs. But the US company Squibb (now Bristol-Myers Squibb) was in tune with this thinking. Its best-selling drug Captopril (an ACE inhibitor used in the treatment of hypertension) was a product that had emerged from a basic research approach. Captopril took 15 years from concept to market; Squibb was prepared to accept a similar timescale for discoveries in the neurosciences.

Within 12 months of the first meeting, an agreement had been signed that gave the university $£ 20$ million over seven arrangement with Squibb means that approval for any paper arising from funded work (but not work funded from other sources) has to be sought. In practice this means a delay of around a week, unless there is material that may be of patentable value, in which case a delay of six months can be requested. But because Squibb is happy to consider a draft with just a summary of the results, says Smith, there have so far been no delays at all.

At about the same time, Cambridge was approaching industrial collaboration in a different way. When the physically scattered department of pharmacology was offered the opportunity to move to a new location on campus, of 70,000 square feet, department head Alan Cuthbert raised finance from independent sources to build new laboratories. The building included a suite of laboratories to be hired out on a long-term basis to a drug company, on "mutually beneficial terms". It was three years before Glaxo, which had earlier been approached, entered a ten-year agreement to move a team of research scientists into the laboratory space, now known as the Glaxo Institute of Applied Pharmacology (GIAP). As well as funding its own research, Glaxo has given $£ 5$ million to support research within the department. Its total investment over the ten years is $£ 16$ million.

There are important differences between the Oxford and Cambridge arrangements, chiefly that company scientists work directly with academics at Cambridge (there are no Squibb personnel in Oxford) and that Cambridge can spend its money entirely as it chooses. There are no restrictions on research topic and decisions about allocation of money are taken within the department. On the other hand, as at Oxford, funded scientists still have to let Glaxo consider their papers before publication. Glaxo has three weeks to turn them around, unless there are items of potential patent interest.

The Oxford and Cambridge experiences has so far proved very happy, in spite of early suspicion borne of historical distrust by academics of industry and its commercial interests. Times have changed and compromises have been made on both sides. For the universities, the injection of secure funds is an immediate reward, and the carefully worded contracts mean that little academic freedom is lost. For Squibb and Glaxo, the risk - though calculated - is greater. It will clearly be at least a decade before the true value to industry of such ventures will be established. But the willingness of these companies to make long-term investments reduces the risk of failure.

NATURE · VOL 361 • 25 FEBRUARY 1993 